\title{
Connessioni religiose su isola a scopo turistico
}

Luigi Corniello

Abstract

Oggetto della ricerca sono le architetture religiose - eremi, monasteri, chiese, cappelle- site su isola, costiere e lacustri, nei Balcani al fine di realizzare una conoscenza dei luoghi attraverso il rilievo e la conseguente creazione di una rete digitale a scopo turistico. Tali strutture presentano una scarna documentazione grafica ed iconografica, pertanto, attraverso alcuni rilievi manuali e strumentali eseguiti nel corso dell'ultimo triennio, si propone una conoscenza dei luoghi attraverso il disegno. I complessi religiosi vengono proposti nelle loro attuali funzioni religiose e nelle loro configurazioni ricche di interesse sull'analisi delle rispettive architetture. Gli impianti architettonici espongono linee armoniose innestate nei complessi urbani o nel verde naturale insulare che avvolge in un'aura di partecipazione contemplativa i complessi nel paesaggio.

Parole chiave

isole, Balcani, rilievo, architettura religiosa, documentazione.

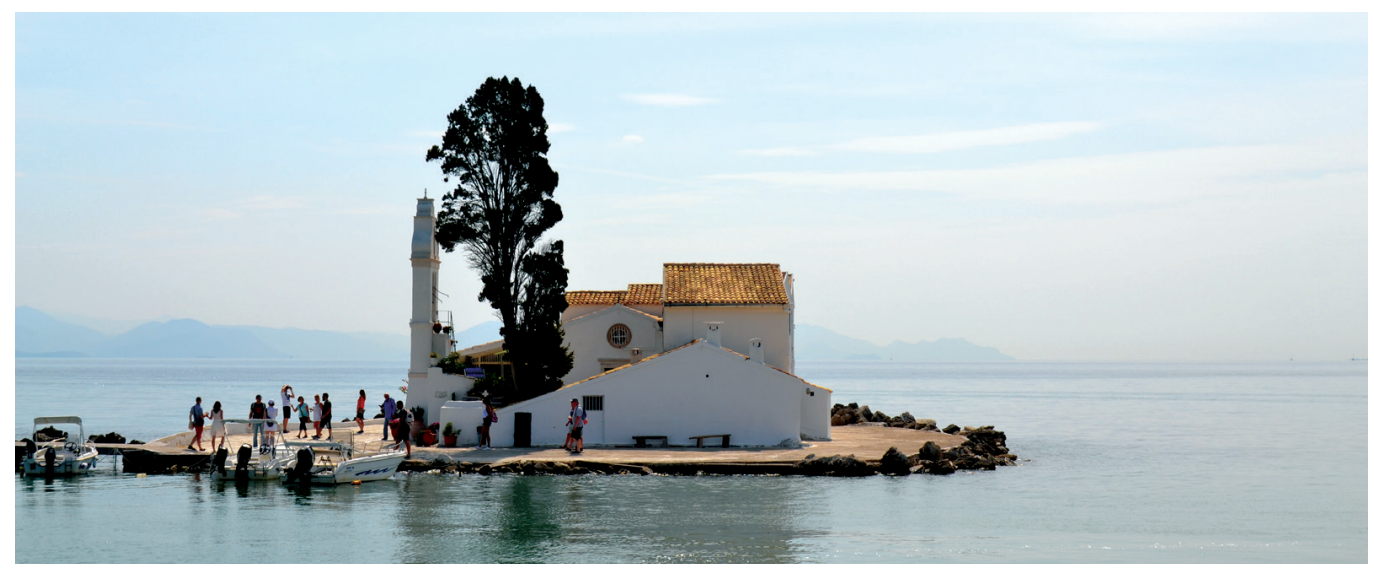




\section{Introduzione}

La ricerca propone lo studio dei complessi religiosi, chiese, cappelle, eremi, monasteri, presenti sulle isole, marine e lacustri dei Balcani analizzandone, attraverso un'accurata attività di rilievo manuale e strumentale oltre alla necessaria analisi delle scarne fonti storiche, le architetture presenti nel paesaggio naturale e antropizzato. La rilettura originale e significativa sia del territorio urbano sia dell'insieme dei corpi strutturali mira a catalogare criticamente i luoghi al fine di proporre itinerari turistici lontani dalle attuali vie del mare consolidate dalle tratte croceristiche. La ricerca propone lo studio del territorio suddiviso per ambiti geografici, da nord a sud, concentrando le analisi sulle architetture religiose su isola presenti in Slovenia, in Croazia, in Montenegro, in Albania ed in Grecia proponendone la conoscenza attraverso il rilievo dei luoghi e delle strutture. In Slovenia viene proposto lo studio planimetrico dell'isola di Bled ed il rilievo della Chiesa di San Martino, in Croazia oggetto della ricerca sono l'Isola di Kosljum con il convento Francescano, la chiesa dell'Annunciazione di Maria e la cappella di San Bernardino e l'isola di Visovac. L'itinerario della ricerca affronta, per quel che riguarda il territorio del Montenegro, lo studio dell'isola della Madonna dello Scalpello con il rilievo della chiesa di San Nicola, dell'isola di San Giorgio con il monastero

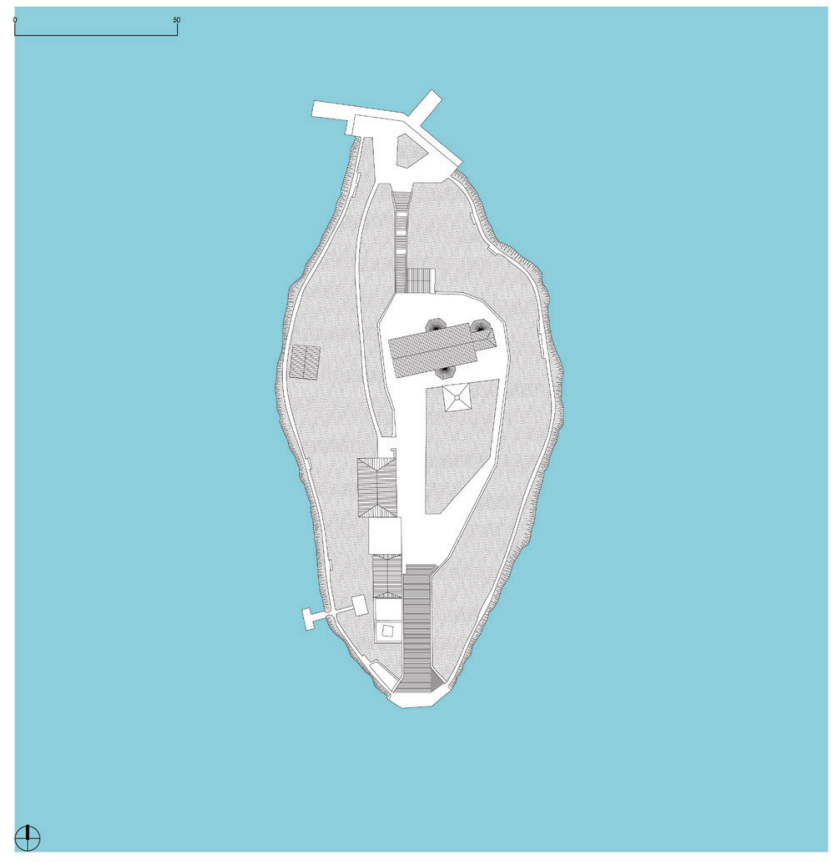

di San Giorgio, dell'isola dello Scoglio del Convento, dell'isola di San Michele, dell'isola di San Nicola con l'omonima chiesa, dell'isola di Santo Stefano oggi prestigioso resort, dell'isola di Santa Domenica, dell'isola di Kom e dell'isola di Vranjina. In Albania viene studiata l'isola di Zvernec ed il monastero ortodosso, mentre per la Grecia sono oggetto della presente ricerca l'isola nel lago Pamvotida, l'isola di Panagia, l'isola di Ai Nikolaos, l'isola di Pontikonissi, l'isola di Stamfani, l'isola di Elafonisos, nonché i tre monasteri presenti sulle isole di Poros, Hydra e Spetses. II tema individuato costituisce un'importante questione scientifica e culturale in grado di confrontarsi sia con le questioni legate alla conoscenza dei luoghi e delle architetture sia con il concetto di protezione e valorizzazione del patrimonio al fine di realizzare un'analisi critica finalizzata alla conservazione ed alla promozione a carattere turistico di un patrimonio, architettonico e paesaggistico di notevole interesse e, in alcuni casi, in forte degrado. 


\section{Le fasi della ricerca}

Le attività di indagine delle architetture religiose hanno previsto diverse campagne di rilievo, realizzate nell'ultimo triennio e finalizzate alla conoscenza delle strutture e del territorio circostante: le analisi grafiche, infatti, hanno prodotto un primo modello geometrico ampliato successivamente con particolari architettonici. È stata inoltre realizzata un'adeguata documentazione fotografica oltre alle verifiche della scarna documentazione di tipo bibliografi$\mathrm{co}$, archivistico, iconografico. In tale scenario della rappresentazione, l'immagine fotografica, oltre a costituire un valore di banca dati al quale si può attingere anche in tempi successivi alla fase di rilievo, appare evi $\neg$ dente la possibilità di interpolare tale dato figurativo statico con elementi informatici di tipo dinamico. Per le attività di conoscenza, si è tenuto conto della strumentazione laser Ryobi applicata su supporto informatico portatile, sia tablet sia smartphone, la quale consente una visione immediata del dato di rilievo sull'immagine fotografica scattata dal supporto, trasformando quest'ultima in un dato dinamico. L'ausilio di tale tecnologia fotografica diviene strumento principale di rilievo poiché contiene sia il dato della misura sia le coordinate geografiche connesse al dispositivo utilizzato, nonché le informazioni relative alla data e all'ora dell'esecuzione della campagna di rilievo. Com'è noto, il rilievo può essere considerato un processo che, partendo dallo stato attuale dell'organismo religioso indagato, cerca di ricostruire a ritroso l'evoluzione storica, avvalendosi di tutti gli strumenti d'indagine, dal rilievo metrico alle ricerche d'archivio e bibliografiche, e capace di illustrare quelle risultanze con indicazioni utili a sostenere una complessiva conoscenza del manufatto. Le attività di rilevo sono state effettuate secondo procedure e metodologie consolidate sia nel campo disciplinare della rappresentazione sia in precedenti e significative esperienze, integrando le varie tecniche necessarie.
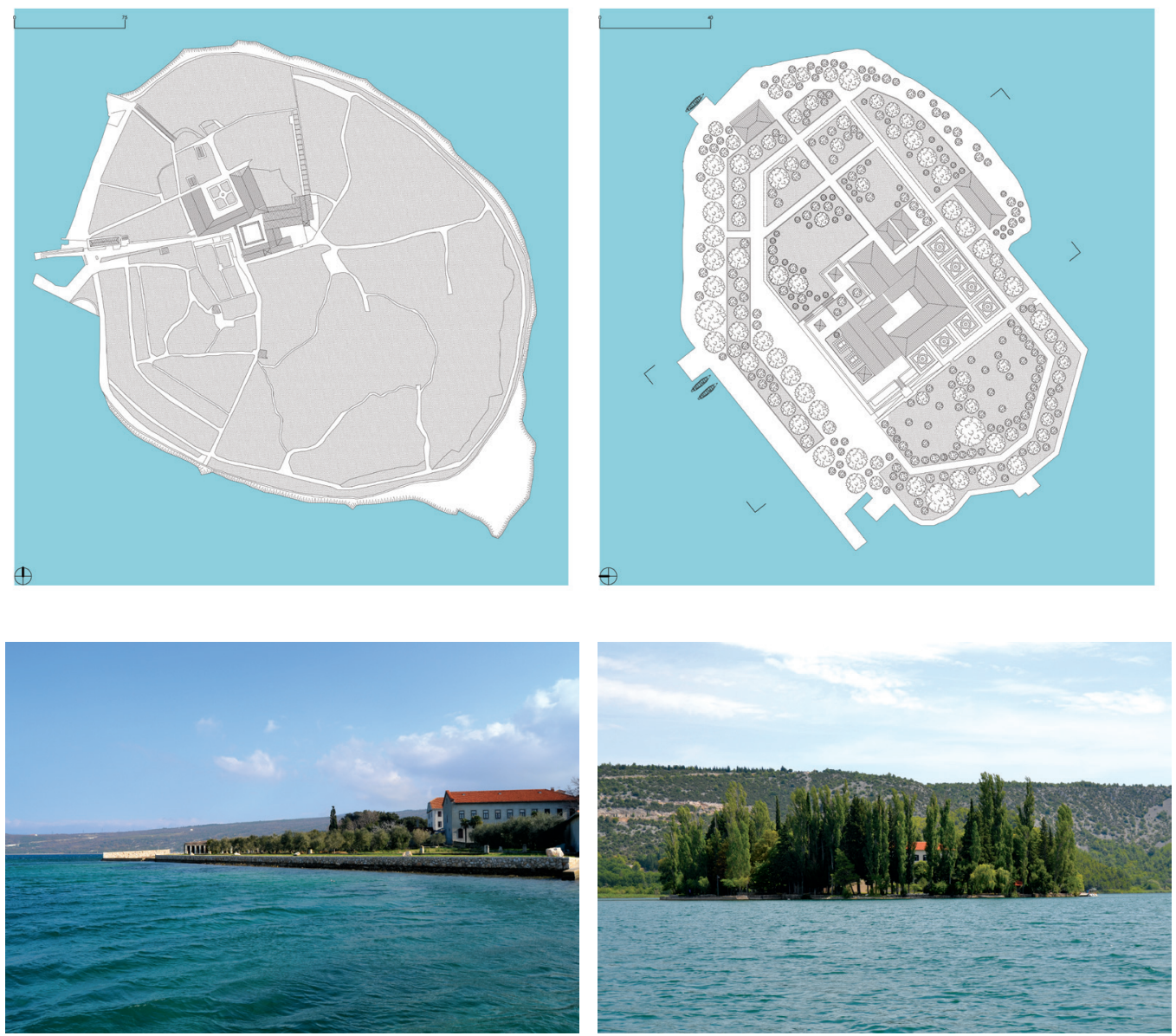


\section{Alcune architetture su isola}

I complessi religiosi vengono proposti, in questo percorso di conoscenza, nelle loro attuali funzioni religiose e nelle loro configurazioni ricche di interesse sull'analisi delle rispettive architetture: edifici comunitari, chiese, strutture di servizio, celle. Gli impianti architettonici espongono linee armoniose innestate nei complessi urbani o nel verde naturale delle isole che avvolge in un'aura di partecipazione contemplativa testimoniata anche da riprese fotografiche recenti di utile approccio di conoscenza dei complessi nel paesaggio. Di alcuni esempi di seguito esaminati, sono state rilevate le dimensioni, gli spazi aperti e chiusi, le configurazioni geografiche nella loro specifica regolarizzazione del sacro perimetro destinato al romitaggio delle fabbriche comunitarie.

II monastero francescano di Visovac in Croazia è sito sull'omonima isola nel lago naturale formato dal fiume Krka, alla fine della gola Grande. I primi documenti relativi al monastero riguardano alcuni scritti dei padri Agostiniani che, nel I445, abbandonano l'isola di Visovac in fuga dall'avanzata dell'esercito turco. Successivamente, vi si insediarono un gruppo di Frati Francescani provenienti dal nord della Croazia che iniziarono ad aumentare artificialmente la superficie l'isola. Nel XV secolo fu eretta l'antica parte del chiostro del monastero, sorretta da alte colonne con bordi tagliati obliqui e le sedici celle. Dal I648 al I672 i padri francescani furono costretti ad abbandonare, nuovamente, il monastero il quale fu poi raso
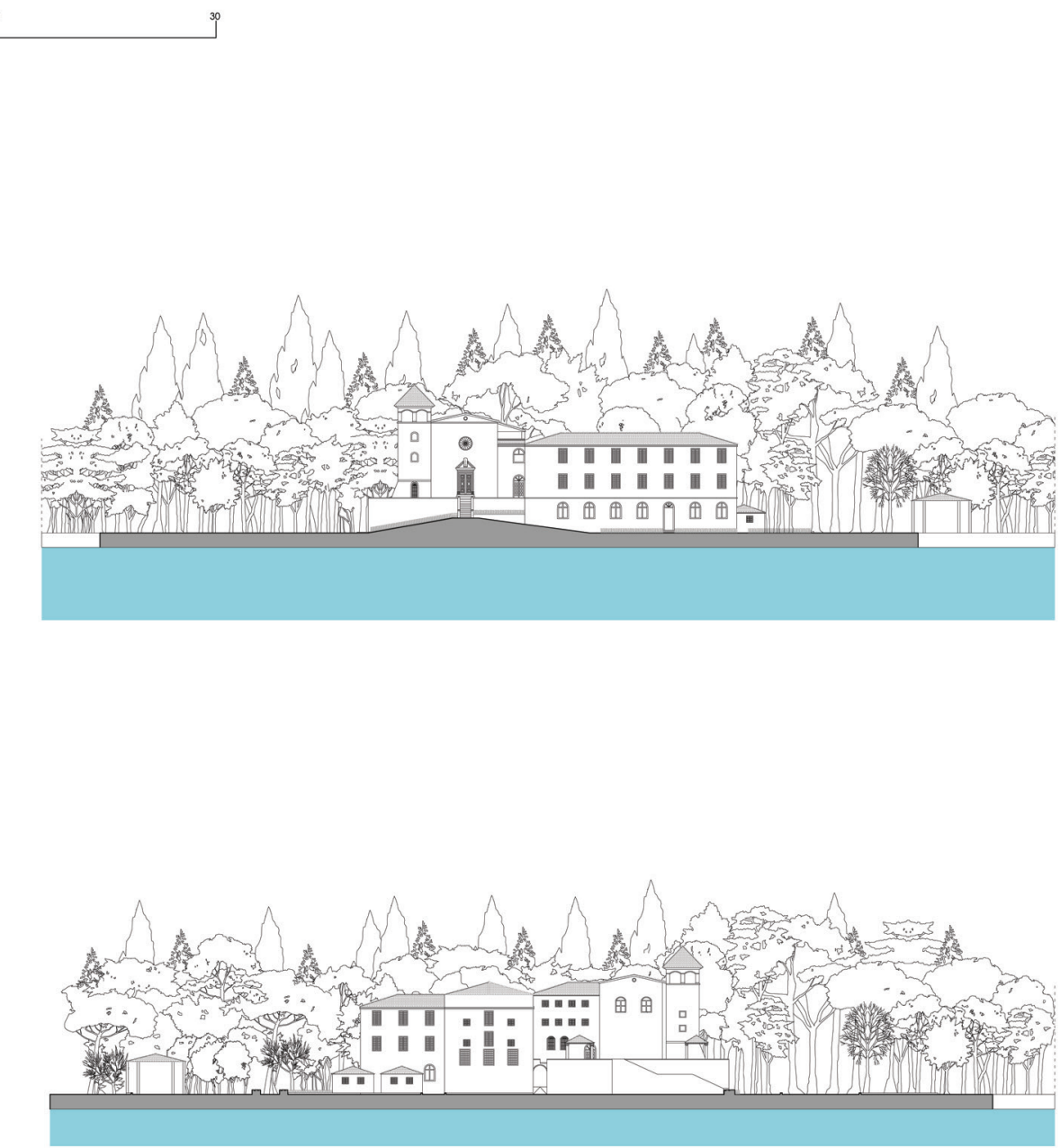


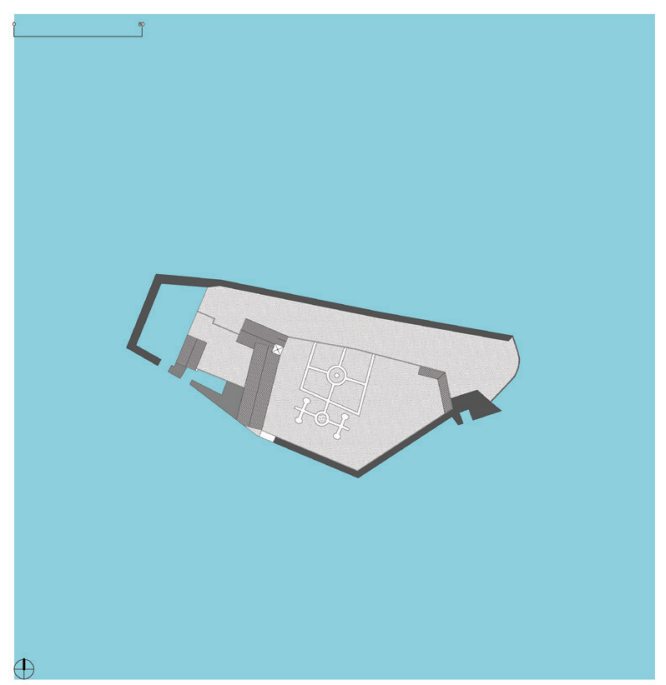

Fig. 5. L'isola di San Giorgio in Croazia. Disegno dell'isola e planimetria generale del monastero (sopra); vista dal mare

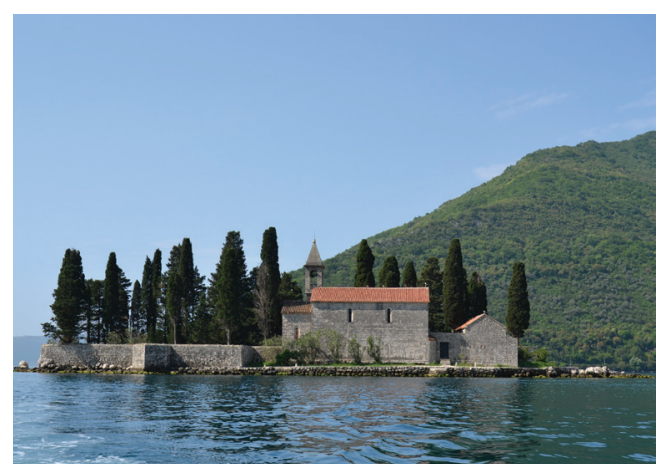

Fig. 6. L'isola dello Scoglio del Convento in Croazia. Disegno dell isola e

planimetria generale della chiesa.

Fig. 7. L'isola di Zvernec in Albania. Disegno dell'isola e planimetria generale del monastero ortodosso.
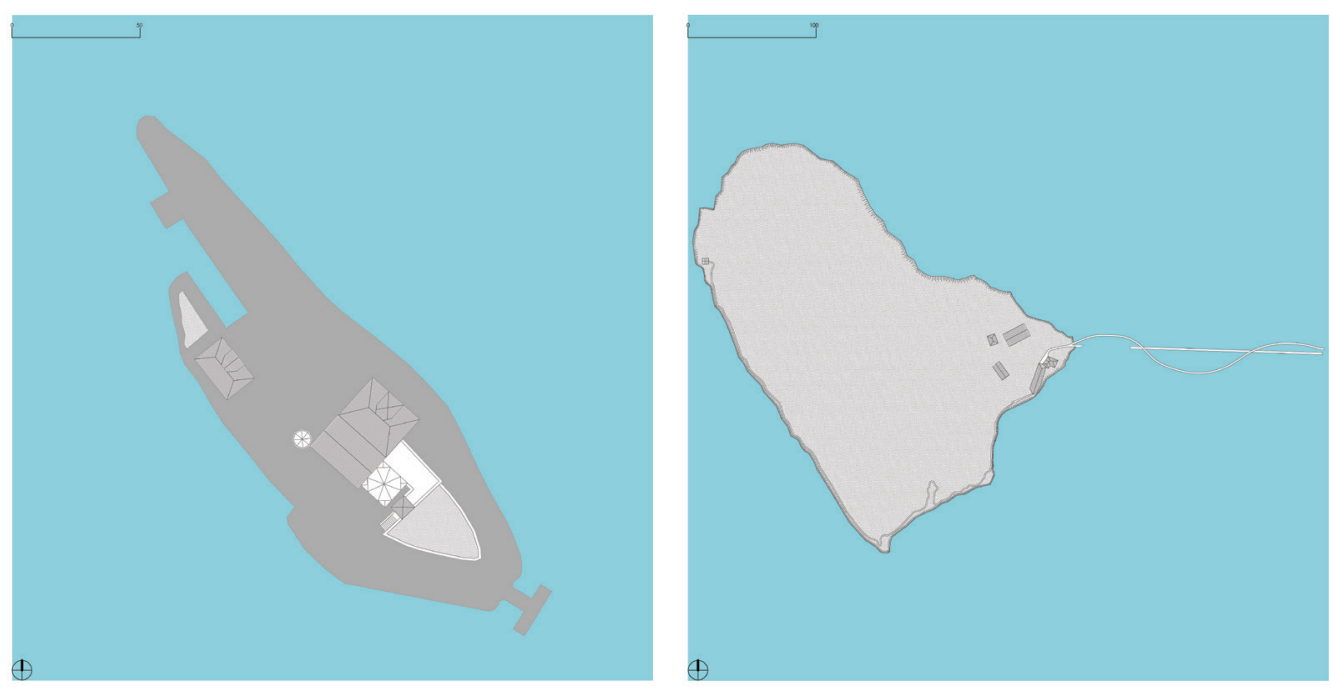
al suolo da un poderoso incendio. La ricostruzione è databile alla prima metà del $18^{\circ}$ secolo, mentre, nel 1755 fu costruito il pozzo e un portico su quattro eleganti ed esili colonne. La primitiva chiesa fu costruita in stile gotico con affreschi di epoca coeva alle pareti e rappresentava la semplicità monastica dei frati che vi si insediarono. Alla fine del diciassettesimo secolo, vi fu ampliamento della struttura: fu allungata la navata, resa più alta e abbellita con ornamenti in stile Barocco. II portale d'accesso fu completamente ridisegnato nel 1694 e posato in opera nello stesso anno. Di notevole interesse è il campanile, sito sul lato sinistro della chiesa costruito nel 1728.

Il monastero della Fonte Primaverile, invece, sito sull'isola di Poros all'interno di una folta pineta a poca distanza dall'omonimo centro urbano, fu fondato nel XVIII secolo nei pressi dell'unica sorgente d'acqua dolce locale che, come narrano le leggende locali, guarì miracolosamente l'arcivescovo di Atene nel 1720. Luogo mistico, riconosciuto nel 1733 dal Patriarca di Costantinopoli sotto propria giurisdizione dal quale ottenne numerosi privilegi economici, ospitò nel 1814 un gruppo di monaci provenienti dal monte Athos che contribuirono alla crescita architettonica e spirituale dei luoghi. Pochi decenni dopo, all'interno dei locali siti al piano terreno, fu fondato il primo orfanotrofio della nazione greca per gli orfani dei guerrieri della Guerra d'indipendenza. Attualmente il monastero è composto da un edificio con corte centrale nella quale si erge la chiesa con cupola ed il campanile. II romitorio a doppio livello presenta nella parte inferiore i locali di servizio quali un refettorio, le cucine, i depositi ed i locali per l'accoglienza dei fedeli, e nella parte superiore le celle dei monaci, di cui 17 occupate.

II Monastero dell'Assunzione della Vergine Maria, inoltre, sito sull'isola di Hydra, occupa una posizione dominante rispetto al porto sul quale si affaccia la ponderosa torre dell'orologio.
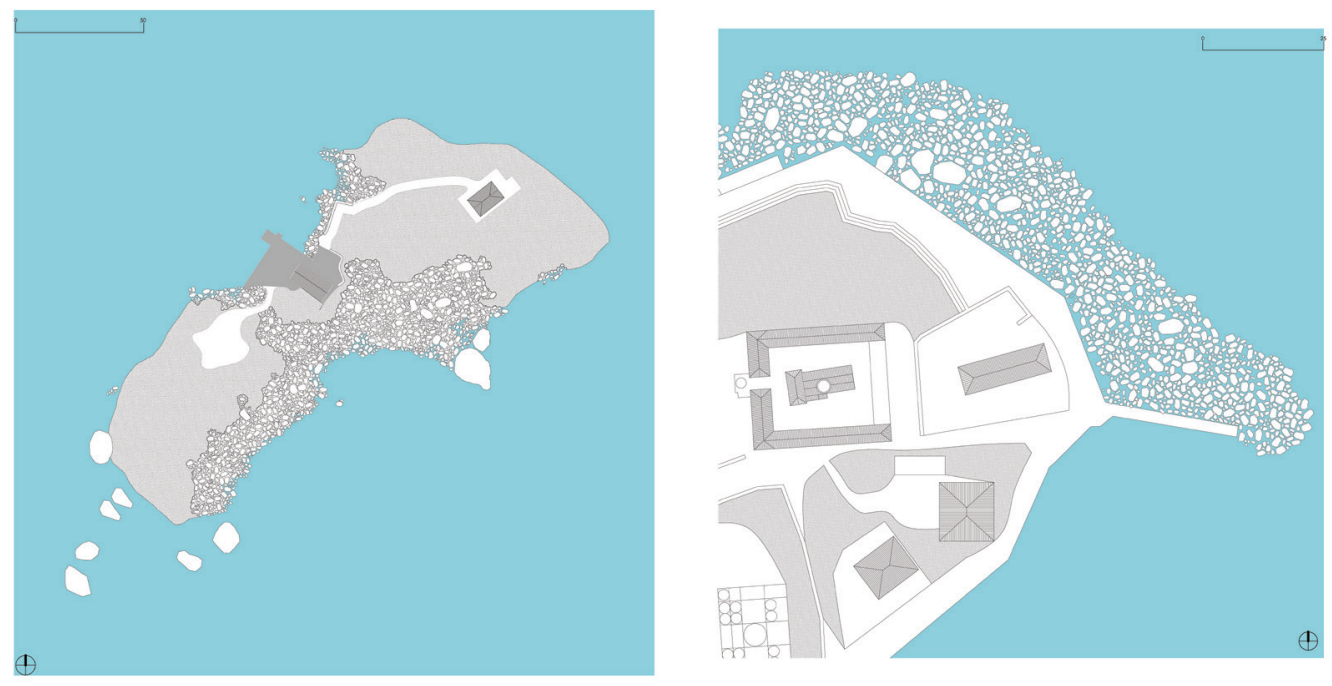

Fig. 8. L'isola di Parga in Grecia. Disegno dell'isola e planimetria delle chiese. vista dal mare (sotto).

Fig. 9. L'isola di Spetsies in Grecia. Particolare dell'isola e planimetria del dell isola e planimetria del del monastero.
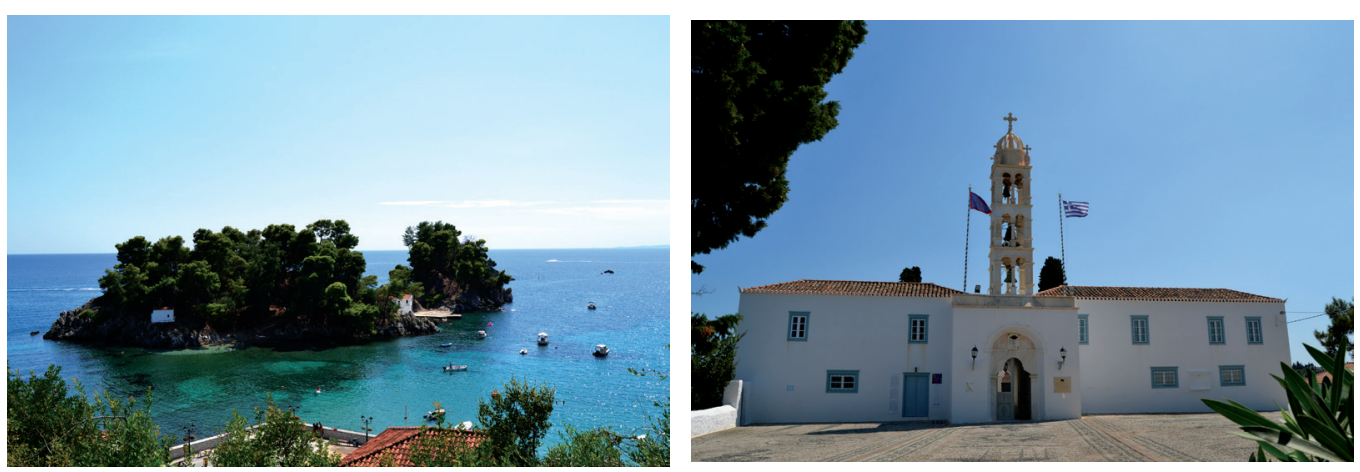


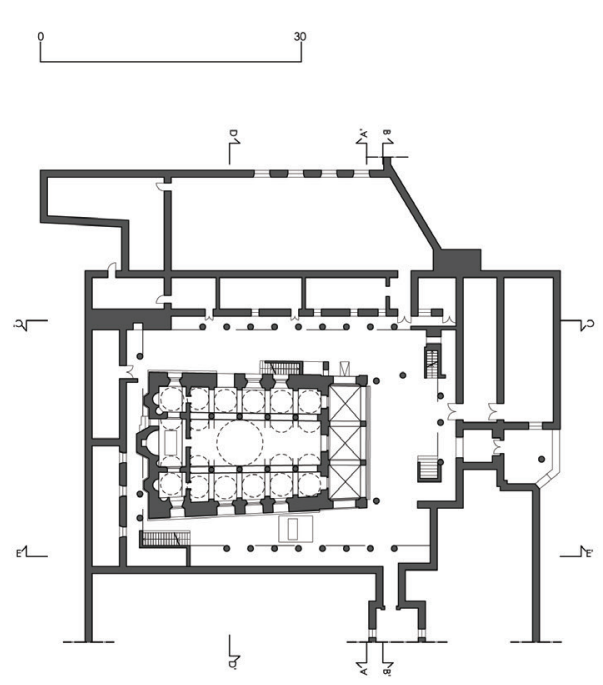

(1)

Fig. 10. L'isola di Hydra in Grecia. Il monastero

Vergine Maria: pianta

piano terra, pianta primo

piano, sezioni trasversali

longitudinali.
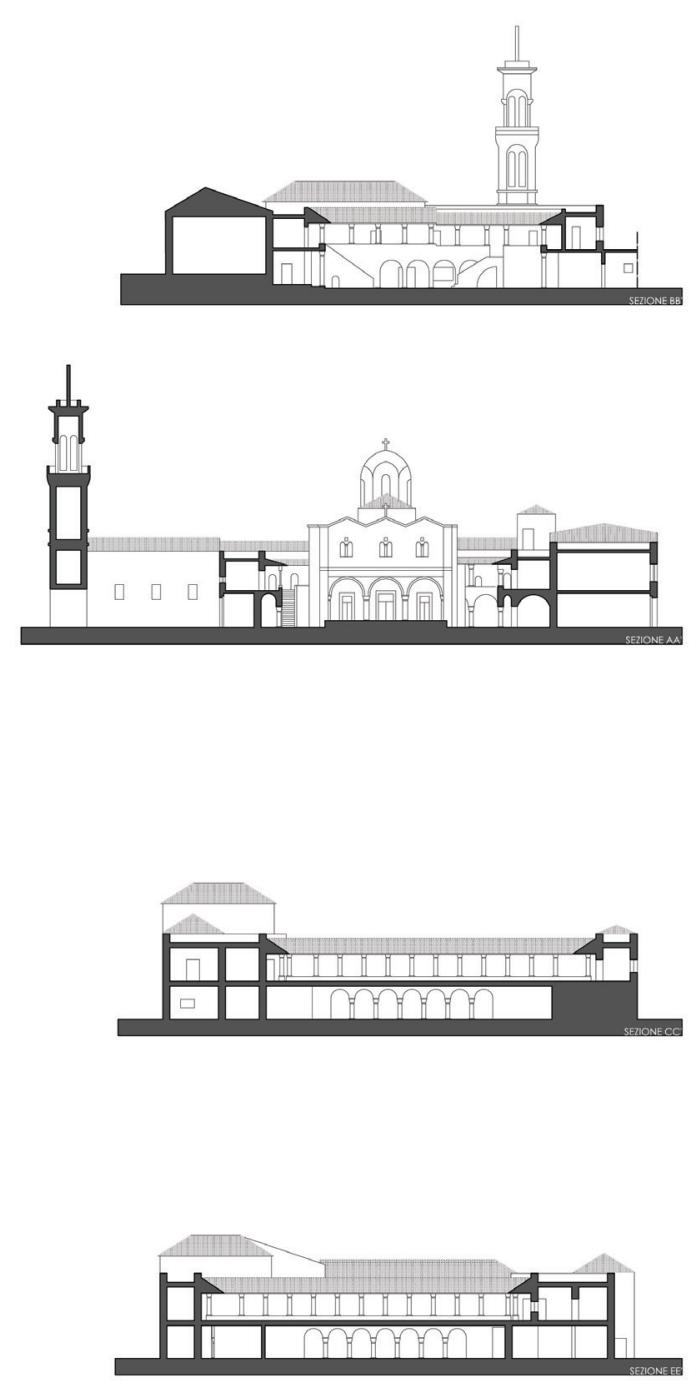
Le fonti documentarie identificano un primo complesso religioso già nel 1643 costituito da una chiesa centrale ed un nucleo di celle di clausura delle 18 religiose. La struttura fu distrutta nel 1774 da un violento terremoto e ricostruita negli anni successivi con influenze architettoniche veneziane derivanti dalla dominazione ad opera della Serenissima in atto nel Mediterraneo. La medesima tipologia edilizia, intitolata dell'Assunzione della Vergine Maria, però, veniva affidata ad un gruppo di monaci ortodossi. Di notevole pregio, è la cattedrale in stile bizantino a tre navate terminanti in tre absidi semicircolari con affreschi del XVIII secolo: l'interno conserva numerose icone in oro e in argento del periodo bizantino e al centro della cupola centrale, pende un imponente lampadario dorato. Nel recinto monastico si ergono due campanili, il primo, risalente al 1643 e rimaneggiato nel I806, a tre livelli è rivestito in marmo e fu progettato dagli architetti veneziani e genovesi per il precedente monastero femminile, il secondo, di dimensioni maggiori, del I 874. Attualmente il cortile laterale ospita i busti di alcuni degli eroi della Guerra d'indipendenza greca del I82 I contro il popolo turco, in ricordo della trasformazione della struttura religiosa in quartiere militare: le celle monastiche, infatti, furono adibite a camere per ammiragli e capitani che gestivano gli attacchi militari verso il vicino oriente.

II monastero di San Nicola a Spetses, infine, è sito lungo la fascia costiera settentrionale dell'isola e nel I82I rappresentò il centro politico, oltre che religioso, della comunità locale. Infatti durante la Guerra d'indipendenza, costituiva il luogo dove venivano concordate le battaglie e le strategie militari ad opera di capitani, signori dell'isola e sacerdoti. La facciata principale, esposta a occidente, è caratterizzata da un ponderoso portale d'ingresso sovrastato dal campanile edificato nel I 805 con il marmo proveniente dall'Isola di Tinos. L'intero complesso a doppio livello con corte centrale con la chiesa a tre navate è caratterizzato da una pavimentazione in ciottoli di mare disposti secondo un disegno geometrico. Verso oriente l'edificio è caratterizzato da un solo piano, quello terreno, mentre al primo piano vi è un terrazzo panoramico sul golfo circostante dove affaccia il portico che conduce alle celle dei monaci.

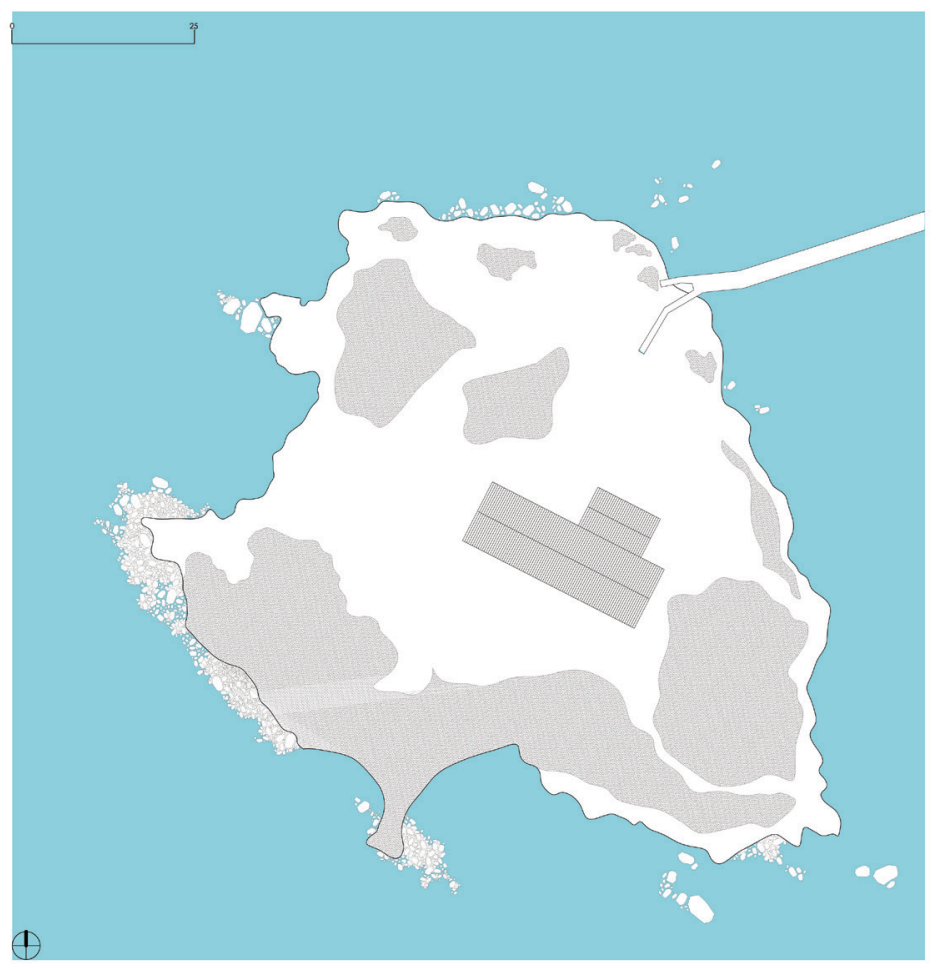




\section{Conclusioni}

Dalle letture di documenti e dai rilievi effettuati emergono gli aspetti strutturali, le valenze formali e le relazioni che hanno consentito di procedere a ritroso prendendo in considerazione l'ipotesi di risalire alla rappresentazione archetipa e, quindi, alla prefigurazione progettuale originaria. La fedele documentazione di alcuni principali elementi architettonici dimostra l'alto valore simbolico delle strutture il cui rapporto si è consolidato nei secoli. Affrontare questo tema ha presupposto l'articolazione di due fasi: la prima relativa al disegno di progetto, con lo studio delle poche fonti storiche rinvenute, la seconda fase interessata alla descrizione dei luoghi, cioè il rilievo.

È da sottolineare che conoscere gli insediamenti religiosi su isola nei Balcani significa confrontarsi con l'eredità del passato e il tessuto residenziale ovvero acquisirne le strutture relativamente a quanto si conserva del patrimonio architettonico ed ambientale da tutelare quale segno forte attuale e del futuro benessere culturale e sociale.

\section{Riferimenti bibliografici}

AA.W. (2004). Spetses. Atene: Micheal Toubis Publication.

AA.W. (20।4). Holy Monastery of the life-Giving Spring. Poros: Monastery press.

Apollonio Fabrizio I. (20।0). La modellazione digitale. Bologna: Clueb.

Barba Salvatore, Cardone Vito (20 I 3). Modelli grafici dell'architettura e del territorio. Santarcangelo di Romagna: Maggioli.

Bertocci Stefano, Bini Marco (2012). Manuale di rilievo architettonico urbano. Torino: Città studi edizioni.

Bianchini Carlo (20I I). Rilievo Modellazione e Studio Geometrico delle Cupole. Roma: Edizioni PreProgetti.

Brusaporci Stefano (2007). Modelli interpretativi dell'architettura medievale. L'Aquila: Arkhè.

Capone Mara (20I2). Geometria per l'Architettura. Napoli: Giannini Editore.

Guter Josef (2008). I monasteri cristiani. Roma: Edizioni Arkeios.

Loudon Michael (2018). Hydra. An Island and its architecture. Vienna: Phoibos Verlag.

Messina Barbara (2012). The domes of the Amalfi Coast: survey and digital representation of complex shapes. Firenze: Nardini Editore.

\section{Autore}

Luigi Corniello, Università della Campania “Luigi Vanvitelli”, luigi.corniello@unicampania.it

Per citare questo capitolo: Luigi Corniello (2020). Connessioni religiose su isola a scopo turistico/Religious connections on the island for tourist purposes. In Arena A., Arena M., Brandolino R.G., Colistra D., Ginex G., Mediati D., Nucifora S., Raffa P. (a cura di). Connettere. Un disegno per annodare e tessere. Atti del $42^{\circ}$ Convegno Internazionale dei Docenti delle Discipline della Rappresentazione/Connecting. Drawing for weaving relationships. Proceedings of the 42th International Conference of Representation Disciplines Teachers. Milano: FrancoAngeli, pp. 1994-201 I. 


\section{Religious Connections on the Island for Tourist Purposes}

Luigi Corniello

Abstract

The object of the research is religious architecture - hermitages, monasteries, churches, chapels - located on islands, coasts and lakes in the Balkans in order to achieve a knowledge of the places through the survey and the consequent creation of a digital network for tourism. These structures present a scarce graphic and iconographic documentation, therefore, through some manual and instrumental surveys carried out during the last three years, we propose a knowledge of the places through drawing. The religious complexes are proposed in their current religious functions and in their configurations rich in interest in the analysis of their respective architectures. The architectural installations display harmonious lines grafted into the urban complexes or the natural island greenery that envelops the complexes in the landscape in an aura of contemplative participation.

Keywords

islands, Balkans, survey, religious architecture, documentation.

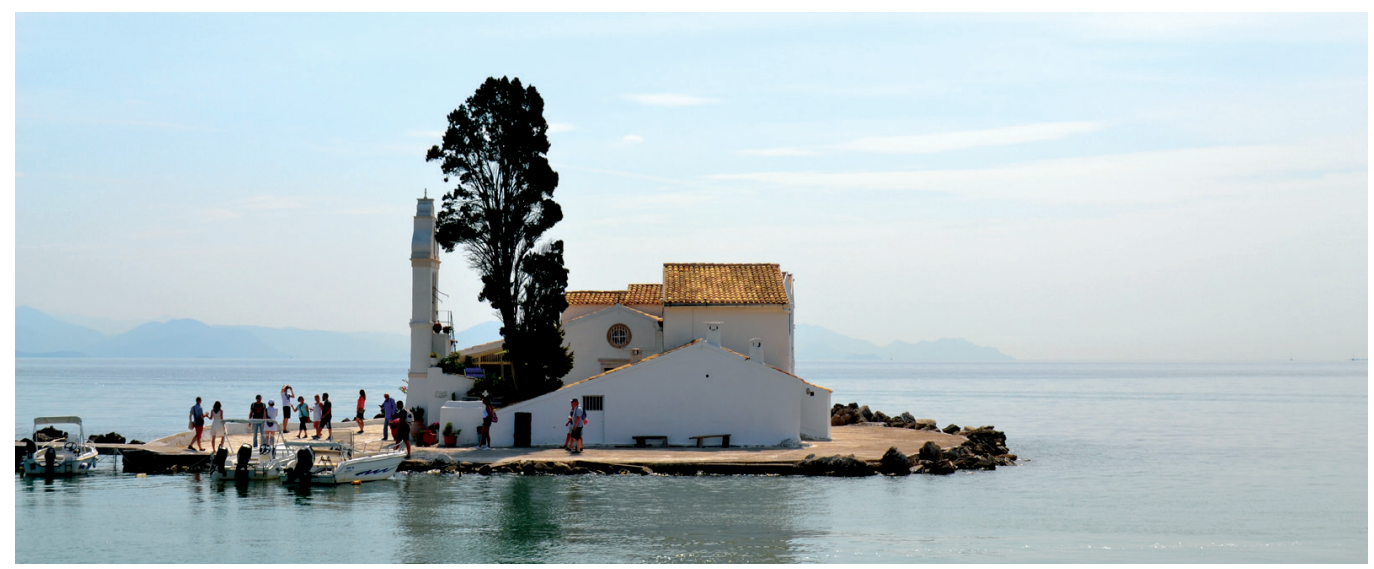




\section{Introduction}

The research proposes the study of religious complexes, churches, chapels, hermitages, monasteries, present on the islands, marinas and lakes of the Balkans by analyzing, through an accurate manual and instrumental survey as well as the necessary analysis of the scarce historical sources, the architecture present in the natural and man-made landscape. The original and significant reinterpretation of both the urban territory and of all the structural bodies aims at critically cataloguing the places in order to propose tourist itineraries far from the current sea routes consolidated by the cruise routes. The research proposes the study of the territory divided by geographical areas, from north to south, concentrating the analysis on religious architecture on islands in Slovenia, Croatia, Montenegro, Albania and Greece, proposing the knowledge through the survey of places and structures. In Slovenia the planimetric study of the Island of Bled and the survey of the Church of St. Martin is proposed, in Croatia the subject of the research are the Island of Kosljum with the Franciscan Convent, the Church of the Annunciation of Mary and the Chapel of St. Bernardino and the Island of Visovac. The research itinerary deals with the study of the Island of Our Lady of Chisel with the relief of the Church of St. Nicholas, the Island of St. George with the Mo-

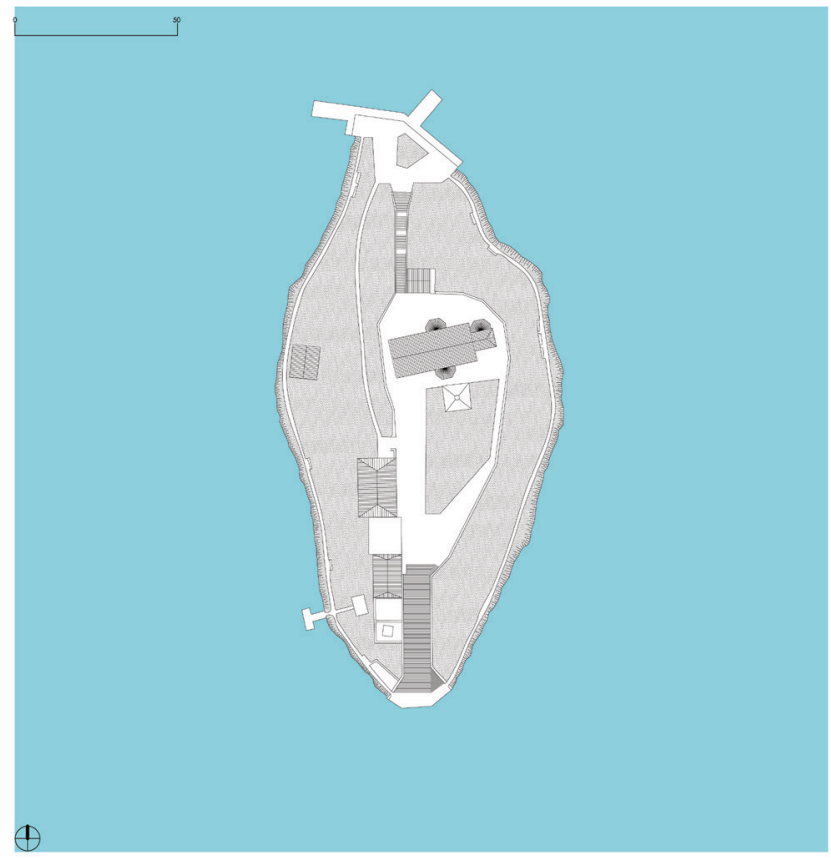

nastery of St. George, the Island of the Convent Rock, the Island of St. Michael, the Island of St. Nicholas with the church of the same name, the Island of St. Stephen, today a prestigious resort, the Island of St. Sunday, the Island of Kom and the Island of Vranjina. In Albania the Island of Zvernec and the Orthodox Monastery are studied, while for Greece the present research focuses on the Island in the Pamvotida Lake, the Island of Panagia, the Island of Ai Nikolaos, the Island of Pontikonissi, the Island of Stamfani, the Island of Elafonisos, as well as the three monasteries on the islands of Poros, Hydra and Spetses. The theme identified is an important scientific and cultural issue that is able to confront both the issues related to the knowledge of places and architectures and the concept of protection and enhancement of heritage in order to carry out a critical analysis aimed at the conservation and promotion of a heritage, architectural and landscape of great interest and, in some cases, in strong degradation. 


\section{The stages of research}

The activities of investigation of religious architecture have included several survey campaigns, carried out in the last three years and aimed at the knowledge of the structures and the surrounding area: the graphic analysis, in fact, have produced a first geometric model later expanded with architectural details. Adequate photographic documentation has also been carried out, in addition to checking the scarce bibliographic, archival and iconographic documentation. In this scenario of the representation, the photographic image, in addition to constituting a database value that can be drawn from even after the survey phase, appears to be able to interpolate this static figurative data with dynamic computer elements. For the knowledge activities, we have taken into account the Ryobi laser instrumentation applied on a portable computer support, both tablet and smartphone, which allows an immediate vision of the relief data on the photographic image taken from the support, transforming it into a dynamic data. The use of this photographic technology becomes the main surveying tool since it contains both the measurement data and the geographical coordinates connected to the device used, as well as information regarding the date and time of the survey campaign. As is well known, the survey can be considered a process that, starting from the current state of the religious body under investigation, tries to reconstruct the historical evolution backwards, using all the instruments of investigation, from metric survey to archive and bibliographic research, and able to illustrate those results with useful indications to support an overall knowledge of the artefact. The surveying activities have been carried out according to procedures and methodologies consolidated both in the disciplinary field of representation and in previous and significant experiences, integrating the various necessary techniques.
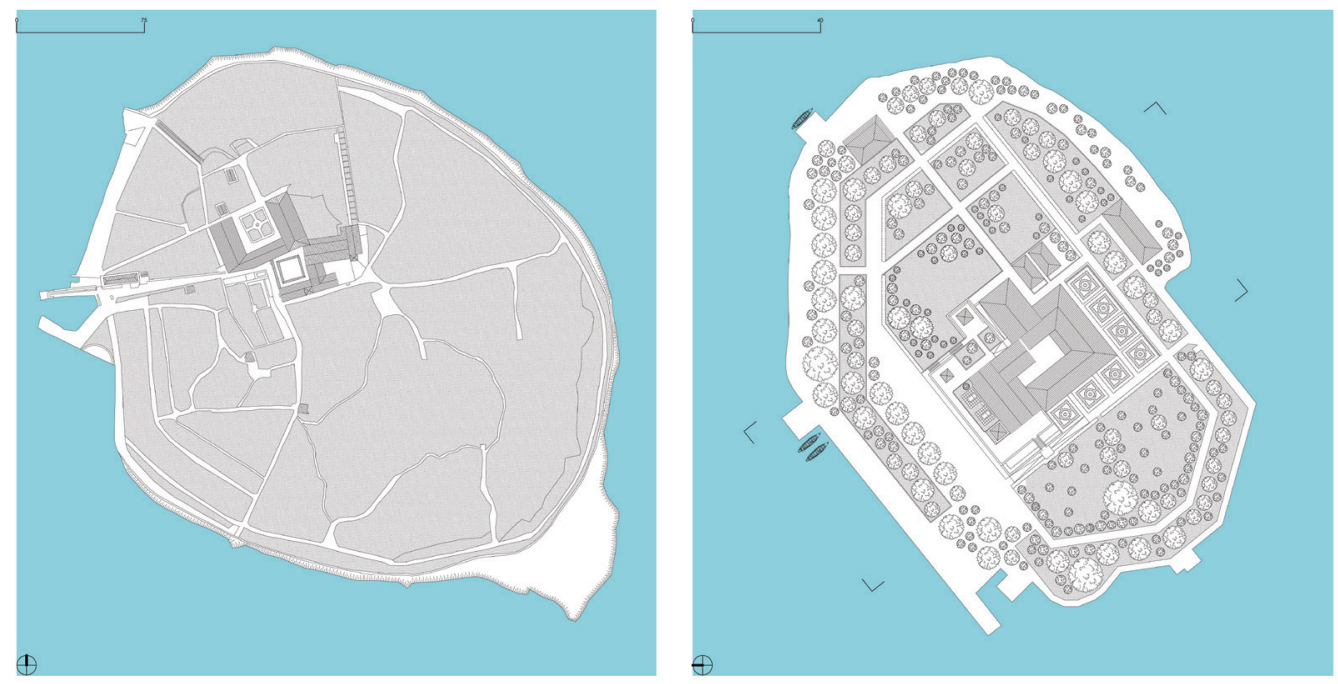

Fig. 2. The island of Kolsjum in Croatia. Drawing of the island with the Franciscan monastery (above); view from the sea (bottom).

Fig. 3. The island of Visovac in Croatia. Drawing of the island with the Franciscan monastery (above); view from the sea (bottom)
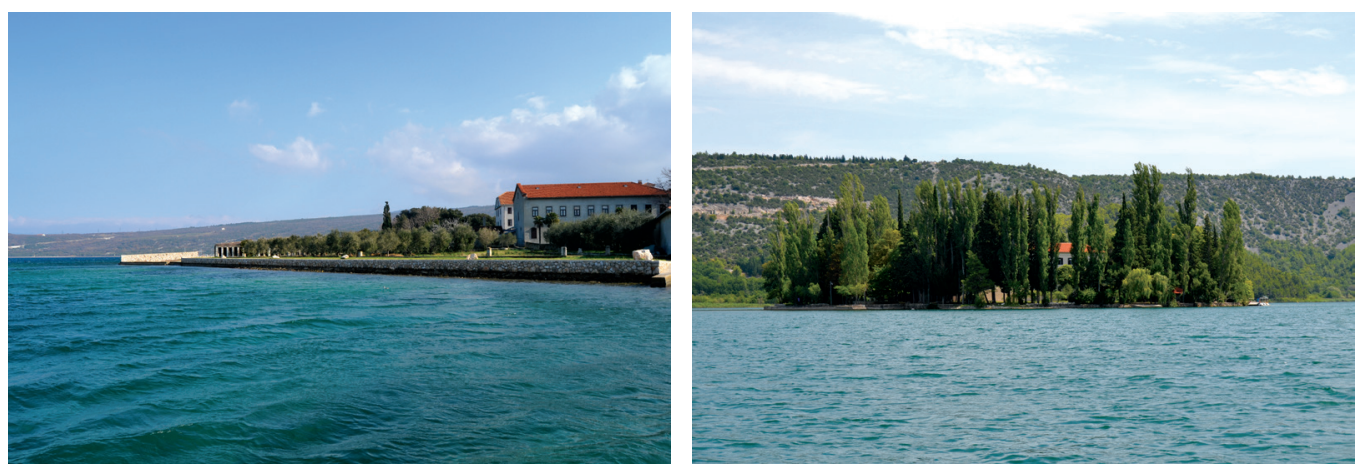


\section{Some architecture on the island}

The religious complexes are proposed, in this journey of knowledge, in their current religious functions and in their configurations rich in interest in the analysis of their respective architecture: community buildings, churches, service structures, cells. The architectural installations display harmonious lines grafted into the urban complexes or into the natural greenery of the islands which envelops them in an aura of contemplative participation also witnessed by recent photographic footage of a useful approach to knowledge of the complexes in the landscape. Of some of the examples examined below, the dimensions, the open and closed spaces, the geographical configurations in their specific regularization of the sacred perimeter intended for the hermitage of community factories have been noted. The Franciscan Monastery of Visovac in Croatia is located on the island of the same name in the natural lake formed by the river Krka, at the end of the Great Gorge. The first documents related to the monastery concern some writings of the Augustinian Fathers who, in 1445, left the island of Visovac in flight from the advance of the Turkish army. Later, a group of Franciscan Friars from northern Croatia settled there and began to artificially increase the surface of the island. In the I5th century the old part of the monastery cloister was erected, supported by high columns with slanted edges and sixteen cells. From 1648 to 1672 the Franciscan fathers were forced to abandon the monastery again, which was then
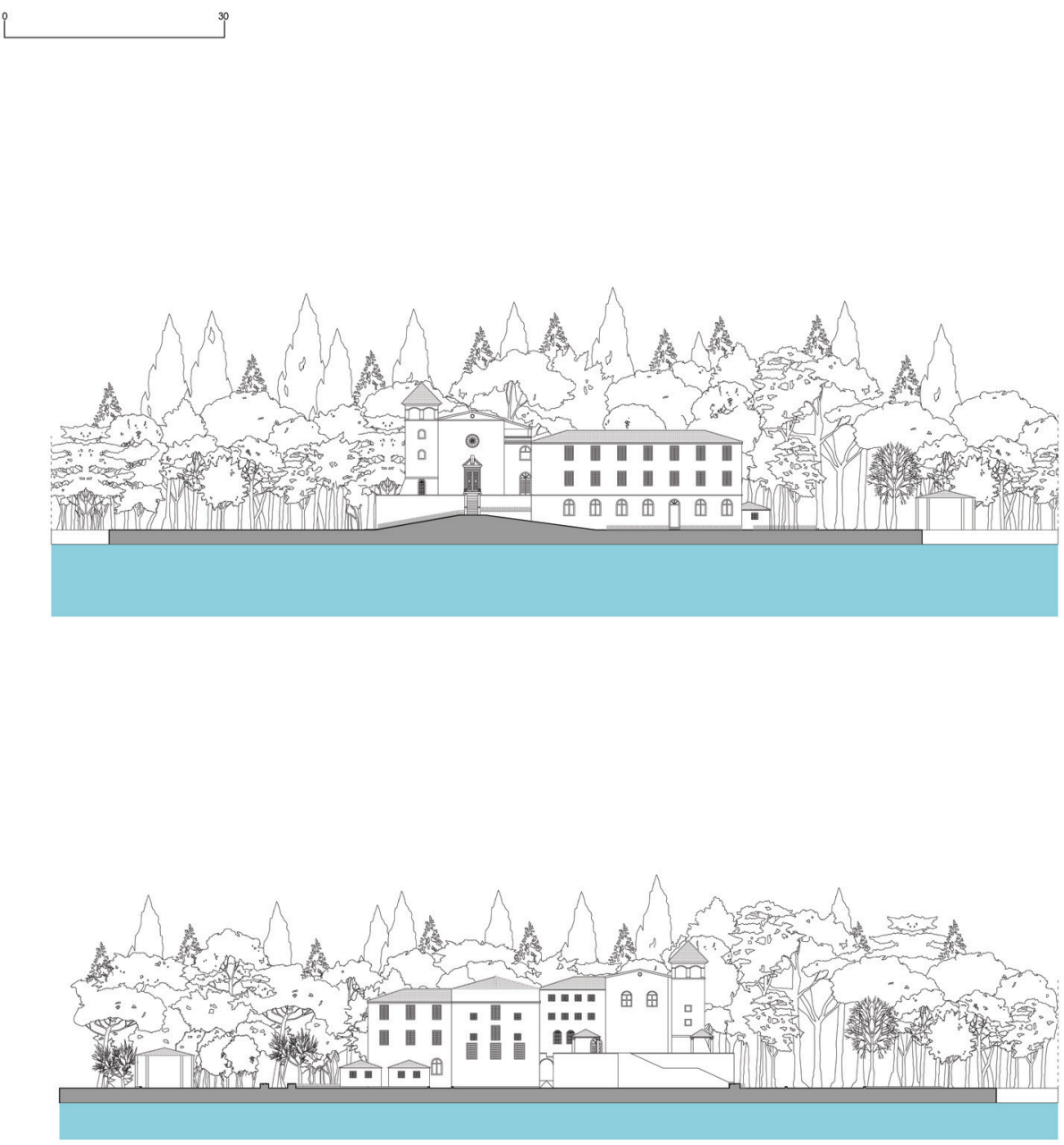


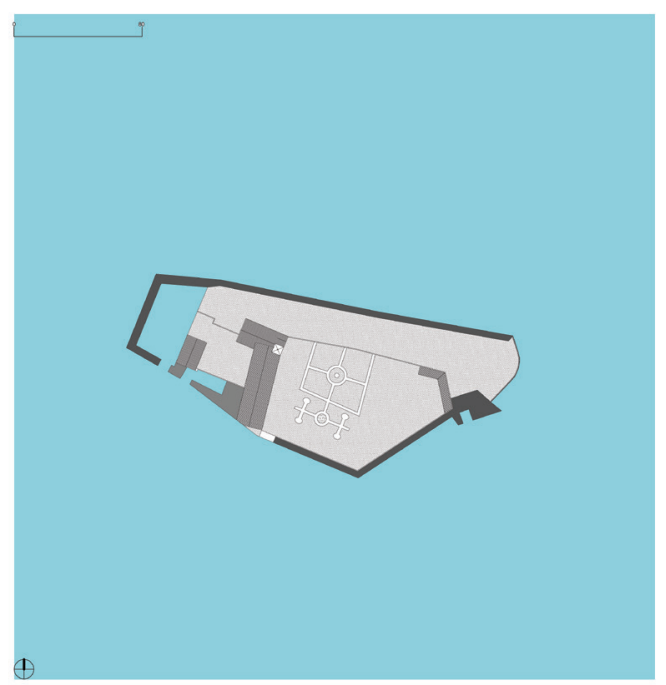

Fig. 5. The island of St. George in Croatia. Drawing of the island and gener plan of the monaster $y$ (above); view from the sea (bottom).

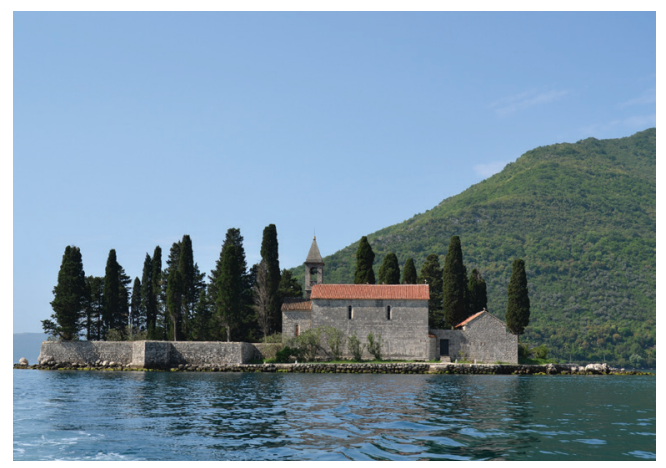

Fig. 6. The island of Convent Rock in Croatia Drawing of the island and general plan of the church.

Fig. 7.The island of Zvernec in Albania. Drawing of the island and genera plan of the Orthodox monastery.
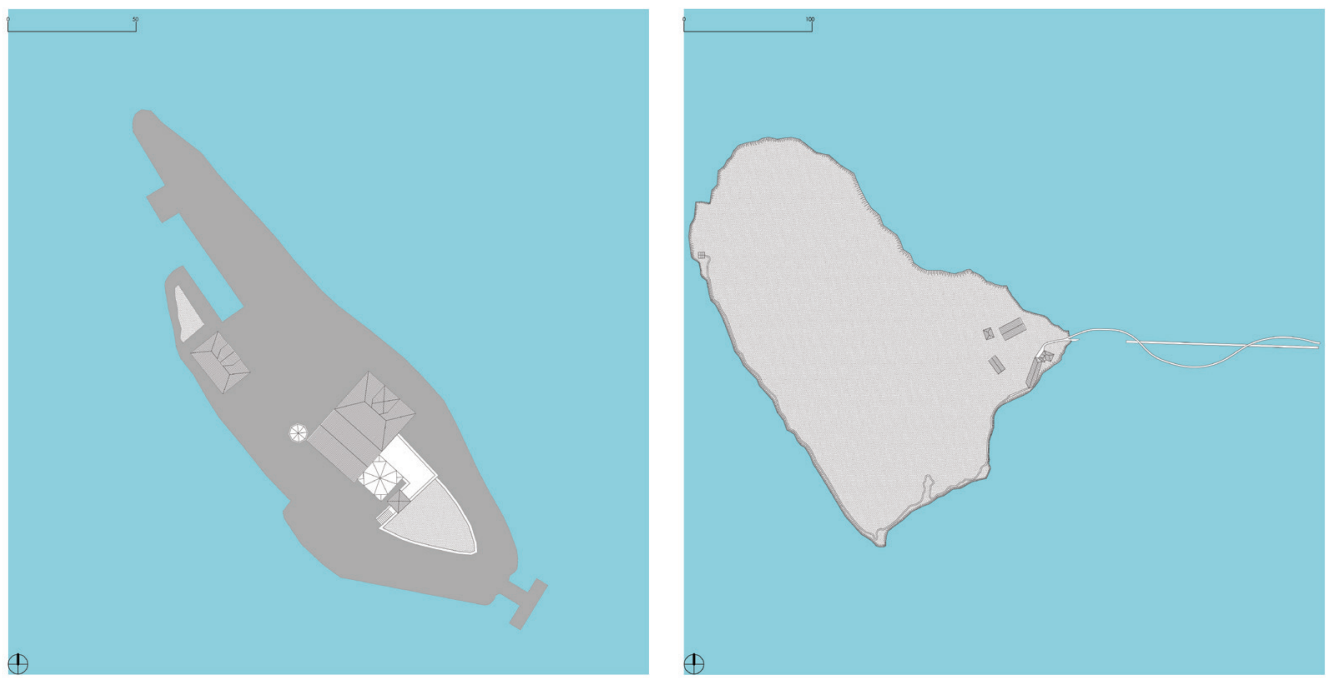
razed to the ground by a powerful fire. The reconstruction can be dated back to the first half of the I 8th century, while in 1755 the well and a portico were built on four elegant and slender columns. The primitive church was built in Gothic style with contemporary frescoes on the walls and represented the monastic simplicity of the monks who settled there. At the end of the 17th century, the structure was enlarged: the nave was lengthened, made taller and embellished with Baroque ornaments. The entrance portal was completely redesigned in 1694 and installed in the same year. Of great interest is the bell tower, located on the left side of the church built in 1728.

The Monastery of the Spring Fountain, on the other hand, located on the island of Poros in a thick pine forest not far from the town of the same name, was founded in the 18th century near the only local fresh water spring which, as local legends tell, miraculously healed the Archbishop of Athens in 1720. A mystical place, recognized in 1733 by the Patriarch of Constantinople under his own jurisdiction from which he obtained numerous economic privileges, in 1814 it hosted a group of monks from Mount Athos who contributed to the architectural and spiritual growth of the place. A few decades later, within the premises on the ground floor, the first orphanage of the Greek nation was founded for the orphans of the warriors of the War of Independence. Currently the Monastery consists of a building with a central courtyard in which stands the Church with a dome and a bell tower. The double level hermitage has in the lower part the service rooms such as a refectory, kitchens, storerooms and rooms for the reception of the faithful, and in the upper part the monks' cells, 17 of which are occupied.

The Monastery of the Assumption of the Virgin Mary, located on the island of Hydra, occupies a dominant position with respect to the port overlooked by the ponderous clock
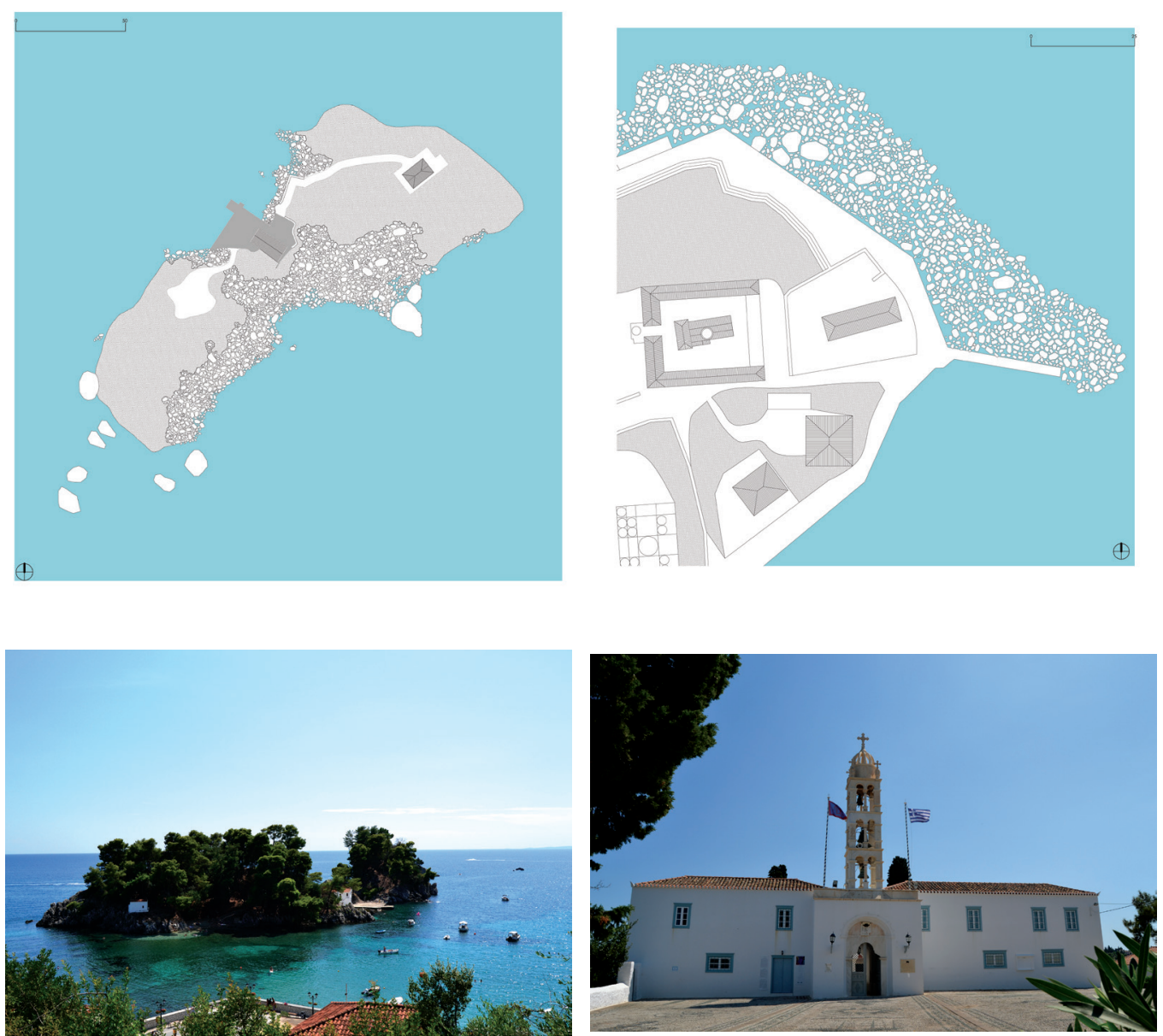


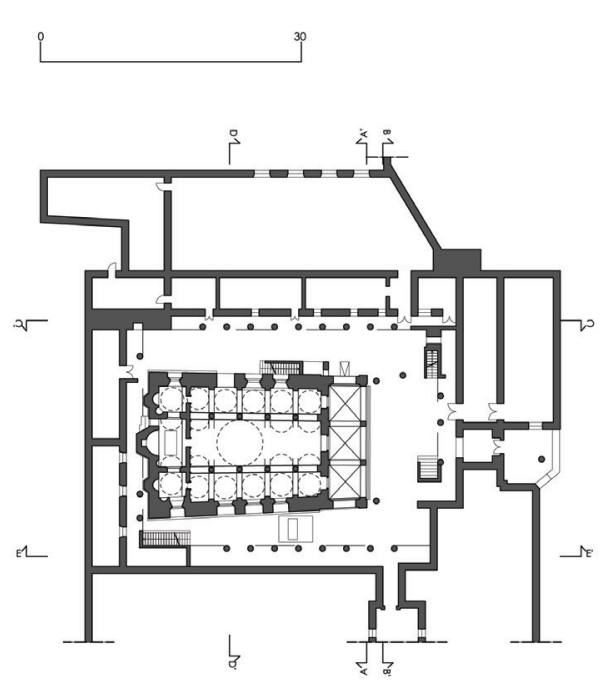

(1)

Fig. 10. Hydra Island in Greece. The monastery of the Assumption of the Virgin Mary. ground floor plan, first floor plan, cross-sections an
longitudinal sections.
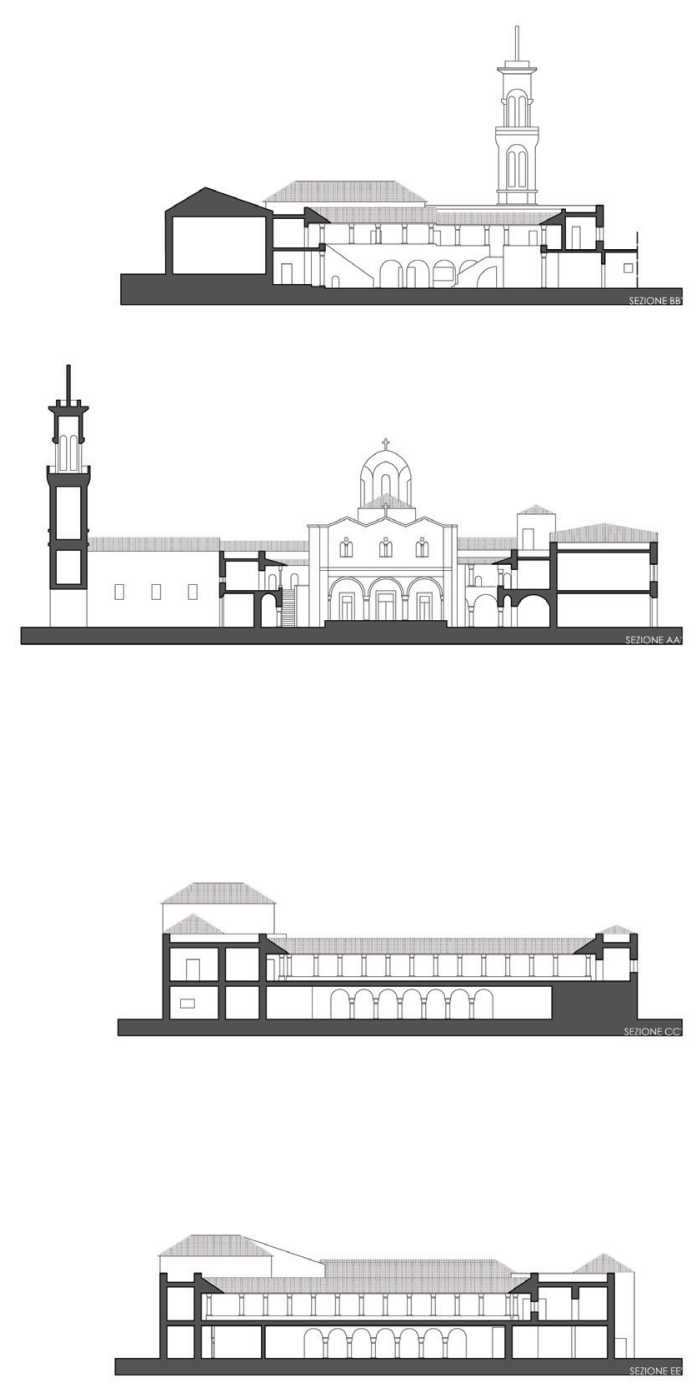
tower. Documentary sources identify a first religious complex already in 1643 consisting of a central church and a nucleus of cloistered cells of the 18 religious women. The structure was destroyed in 1774 by a violent earthquake and rebuilt in the following years with Venetian architectural influences deriving from the Serenissima domination in the Mediterranean. The same type of building, named after the Assumption of the Virgin Mary, however, was entrusted to a group of Orthodox monks. The Cathedral, in Byzantine style, has three naves ending in three semi-circular apses with frescoes from the 18th century: the interior preserves numerous icons in gold and silver from the Byzantine period and in the centre of the central dome hangs an imposing gilded chandelier. In the monastic enclosure there are two bell towers, the first, dating back to 1643 and remodelled in 1806, on three levels is covered in marble and was designed by Venetian and Genoese architects for the previous women's monastery, the second, larger, dating back to 1874. Currently the side courtyard houses the busts of some of the heroes of the GreekWar of Independence of I 82 I against the Turkish people, in memory of the transformation of the religious structure into a military quarter: the monastic cells, in fact, were used as chambers for admirals and captains who managed the military attacks towards the Near East.

The Monastery of St. Nicholas in Spetses, finally, is located along the northern coastal strip of the island and in I82I it represented the political, as well as religious, centre of the local community. In fact, during the War of Independence, it was the place where battles and military strategies were agreed upon by captains, lords of the island and priests. The main façade, facing west, is characterized by a ponderous entrance portal surmounted by the bell tower built in 1805 with marble from the island of Tinos. The entire complex on a double level with a central courtyard and a church with a nave and two aisles is characterized by a floor made of sea pebbles arranged according to a geometric design. Towards the east the building is characterized by a single floor, the ground floor, while on the first floor there is a panoramic terrace overlooking the surrounding gulf where there is a portico leading to the monks' cells.

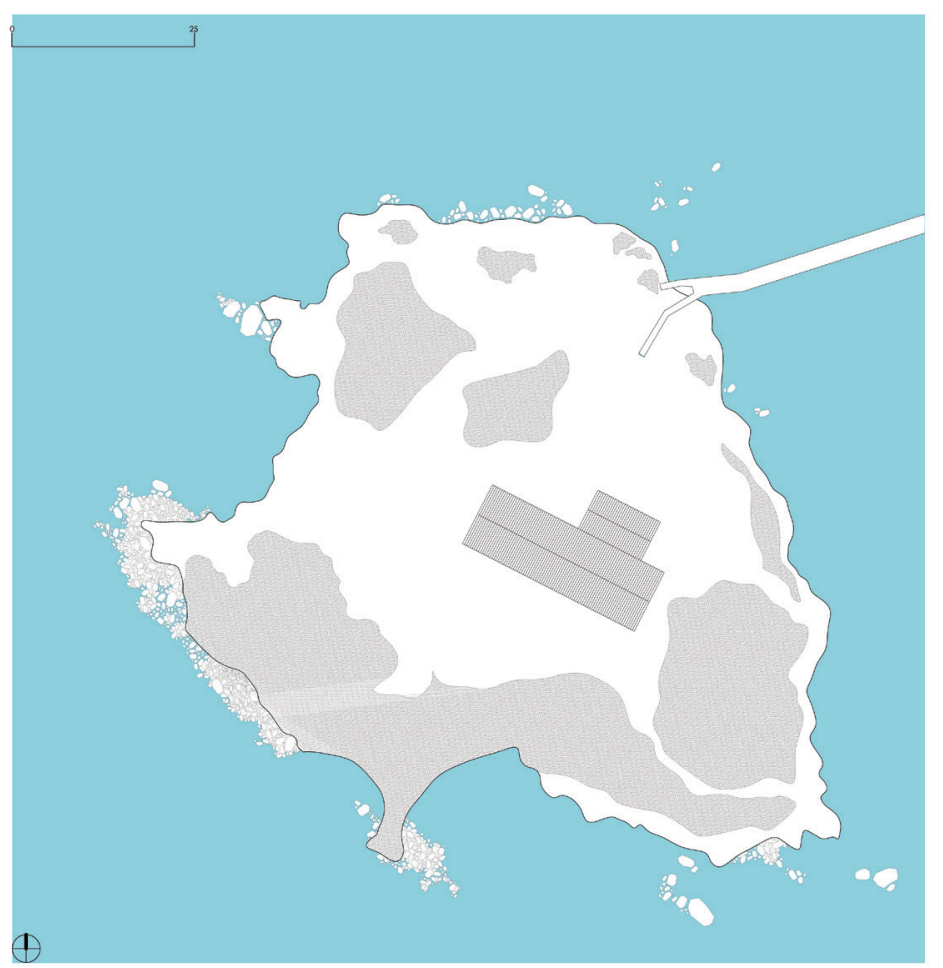




\section{Conclusions}

From the readings of documents and the surveys carried out emerge the structural aspects, the formal values and the relationships that have allowed us to proceed backwards, taking into consideration the hypothesis of going back to the archetypal representation and, therefore, to the original design prefiguration. The faithful documentation of some of the main architectural elements demonstrates the high symbolic value of the structures whose relationship has been consolidated over the centuries. To deal with this theme has assumed the articulation of two phases: the first one related to the project design, with the study of the few historical sources found, the second phase interested in the description of the places, that is the survey.

It should be stressed that knowing the religious settlements on islands in the Balkans means confronting the legacy of the past and the residential fabric, or acquiring the structures regarding the architectural and environmental heritage to be protected as a strong current sign and future cultural and social well-being.

\section{References}

AA.W. (2004). Spetses. Atene: Micheal Toubis Publication.

AA.W. (20 I 4). Holy Monastery of the life-Giving Spring. Poros: Monastery press.

Apollonio Fabrizio I. (20।0). La modellazione digitale. Bologna: Clueb.

Barba Salvatore, Cardone Vito (20 I3). Modelli grafici dell'architettura e del territorio. Santarcangelo di Romagna: Maggioli.

Bertocci Stefano, Bini Marco (20 I2). Manuale di rilievo architettonico urbano. Torino: Città studi edizioni.

Bianchini Carlo (20 I I). Rilievo Modellazione e Studio Geometrico delle Cupole. Roma: Edizioni PreProgetti.

Brusaporci Stefano (2007). Modelli interpretativi dell'architettura medievale. L'Aquila: Arkhè.

Capone Mara (2012). Geometria per l'Architettura. Napoli: Giannini Editore.

Guter Josef (2008). I monasteri cristiani. Roma: Edizioni Arkeios.

Loudon Michael (20।8). Hydra. An Island and its architecture. Vienna: Phoibos Verlag.

Messina Barbara (2012). The domes of the Amalfi Coast: survey and digital representation of complex shapes. Firenze: Nardini Editore.

\section{Author}

Luigi Corniello, Università della Campania “Luigi Vanvitelli”, luigi.corniello@unicampania.it

To cite this chapter. Luigi Corniello (2020). Connessioni religiose su isola a scopo turistico/Religious connections on the island for tourist purposes. In Arena A., Arena M., Brandolino R.G., Colistra D., Ginex G., Mediati D., Nucifora S., Raffa P. (a cura di). Connettere. Un disegno per annodare e tessere. Atti del $42^{\circ}$ Convegno Internazionale dei Docenti delle Discipline della Rappresentazione/Connecting. Drawing for weaving relationships. Proceedings of the 42th International Conference of Representation Disciplines Teachers. Milano: FrancoAngeli, pp. 1994-201 I. 